BARBARA RUBACHA

Uniwersytet Marii Curie-Skłodowskiej, Lublin, Polska

\title{
Wpływ światowego kryzysu gospodarczego na kształtowanie polityki regionalnej w Polsce
}

\author{
The impact of the global economic crisis \\ on the development of regional policy in Poland
}

\begin{abstract}
Streszczenie: Polityka regionalna jest częścią polityki rozwoju kraju. Na skutek kryzysu władze rządowe w wielu krajach, w tym w Polsce, wprowadziły zmiany w swojej polityce regionalnej poprzez kierowanie dodatkowej pomocy dla regionów słabszych strukturalnie. Celem referatu jest pokazanie, jak światowy kryzys gospodarczy wpłynął na zmiany w formułowaniu problemów i wyznaczaniu nowych celów oraz proces realizacji polityki regionalnej. W 2008 roku rząd RP przystąpił do prac nad opracowaniem modelu polityki regionalnej, dostosowanego do obowiązującej polityki spójności Unii Europejskiej. Podstawą tego założenia była nowelizacja ustawy z dnia 7 listopada 2008 roku o zmianie niektórych ustaw w związku z wdrażaniem funduszy strukturalnych i Funduszu Spójności. Przeanalizowano także wpływ funduszy europejskich na gospodarkę polskich regionów. Programy operacyjne Unii Europejskiej są głównym źródłem finansowania i stanowią podstawowy mechanizm realizacji polityki regionalnej w Polsce. Stopień wrażliwości regionu na kryzys oszacowano za pomocą wskaźników: PKB na mieszkańca, stopy bezrobocia i zatrudnienia. Zauważyć można, że charakter polityki regionalnej skupionej na zasadach równości terytorialnej zmienił się na rzecz pobudzania wzrostu gospodarczego oraz natężenia konkurencji w skali regionalnej. Na potrzeby niniejszego opracowania wykorzystano analizę raportów Ministerstwa Rozwoju Regionalnego, raportów Ministerstwa Gospodarki, raportów EoRPA (European Regional Policy Research Consortium) oraz danych Eurostat i GUS. Główną metodą badawczą była analiza opisowa oraz analiza materiałów archiwalnych i statystycznych.
\end{abstract}

\begin{abstract}
Regional policy is a part of the national development policy. As a result of the crisis, the government authorities in many countries, including Poland, have introduced changes in its regional policy by direct additional support for the structurally weak regions. The aim of this paper is to present how the global economic crisis affected the changes in the formulation of the problems, the setting of the new objectives and the implementation of regional policy. In 2008, the government in Poland began to work on developing a new model of regional policy adjusted to the cohesion policy of the EU. The basis for this assumption was the amendment of the Act of 7 November 2008 on the amendment of certain acts in connection with the implementation of the Structural Funds and the Cohesion Fund. Also analyzed was the impact of EU funds on the economy of Polish regions. Operational Programmes of the European Union are the main source of funding and a fundamental mechanism for the implementation
\end{abstract}


of regional policy in Poland. The degree of sensitivity of the region to the crisis was estimated using the following indicators: GDP per capita, unemployment and employment rates. It was found that the nature of regional policy, which was focused on territorial equality has been changed in order to stimulate economic growth and the intensity of competition on a regional scale. For the purposes of this study used were the report analysis of the Ministry of Regional Development, the Ministry of Economy's reports, EoRPA's reports (European Regional Policy Research Consortium) and data of the Eurostat and Central Statistical Office.The main research method was a descriptive analysis and the analysis of archival materials and statistics.

Słowa kluczowe: fundusze strukturalne; kryzys gospodarczy; polityka regionalna; region

Keywords: economic crisis; region; regional policy; structural funds

\section{WSTĘP}

Polityka regionalna stanowi nierozłączną część polityki rozwoju, która pomaga w realizacji celów na poziomie krajowym. Jest to zespół strategicznych działań podejmowanych przez rząd, samorządy województw i inne podmioty władz samorządowych, których głównym celem jest zapewnienie zrównoważonego rozwoju i poprawy konkurencyjności gospodarczej regionów, a także zmierzanie do osiągnięcia spójności społeczno-gospodarczej oraz terytorialnej w skali kraju i regionów (Grosse, 2009a).

Obecnie obowiązującym dokumentem strategicznym, będącym podstawą sposobu planowania oraz prowadzenia polityki regionalnej w Polsce, jest Krajowa Strategia Rozwoju Regionalnego 2010-2020. Polska polityka regionalna jest silnie związana i podporządkowana europejskiej polityce spójności (Szlachta, Zaleski, 2010). Polityka regionalna zajmuje wysoką pozycję wśród polityk, które prowadzi Unia Europejska, przede wszystkim ze względu na jej strategiczny charakter w odniesieniu do wyznaczonych przez UE celów oraz wysokości nakładów finansowych przeznaczonych na jej realizację. Finansowym narzędziem polityki regionalnej UE są fundusze strukturalne, których największymi beneficjentami są nowe państwa członkowskie UE, do których należy także Polska (Tarnawska, 2011).

Fundusze UE są głównym i istotnym źródłem finansowania polityki regionalnej w Polsce. Strategicznym dokumentem określającym priorytety, obszary wykorzystania oraz system wdrażania funduszy unijnych jest Narodowa Strategia Spójności, funkcjonująca również pod nazwą Narodowe Strategiczne Ramy Odniesienia (Dudziak, 2009). Priorytety, obszary wykorzystania oraz system wdrażania funduszy UE są programowane we współpracy z Komisją Europejską (Grosse, 2009a).

Spadek światowego PKB, który nastąpił wskutek kryzysu, sięgnął bilionów dolarów. Zasięg kryzysu oraz jego skala uzależnione były od zmian instytucjonalnych w USA i innych krajach w sektorze finansowym. Nieprawidłowości zaistniałe na rynku kredytów hipotecznych w Stanach Zjednoczonych wywarły niekorzystny wpływ w skali globalnej, choć o różnym stopniu nasilenia. Najbardziej dotknął kraje o wysokorozwiniętej gospodarce, natomiast mniej jego negatywnych skutków zaobserwowano w krajach rozwijających się (Czekaj, 2010). 
W odpowiedzi na kryzys wiele państw UE zmodyfikowało zakres polityki regionalnej, kierując dodatkowe wsparcie do regionów słabszych strukturalnie. Skutki kryzysu w Polsce okazały się w porównaniu z innymi krajami UE dosyć ograniczone. Zauważyć można było przede wszystkim ograniczenia w pozyskiwaniu kredytów bankowych przez przedsiębiorstwa i gospodarstwa domowe (Davies, Kah, Woods, 2010).

Rząd RP w reakcji na kryzys przygotował serię narzędzi finansowych, programowanych według działań antykryzysowych zaakceptowanych przez KE. Przygotowano m.in. program polegający na zwiększaniu skali finansowego wsparcia dla firm, a także zagwarantowaniu pomocy oraz doradztwa pracodawcom. Ograniczony natomiast był wpływ na system wsparcia regionów, czego przyczyną jest współfinansowanie z funduszy strukturalnych w ramach różnych programów operacyjnych. Ich wysokość nie ulega zmianie w krótkim okresie, dlatego też nie są one narażone na działanie kryzysu (EoRPA, 2009).

Pod koniec 2008 roku rząd RP poprzez Ustawę z dnia 8 listopada 2008 roku o zmianie niektórych ustaw w związku z wdrażaniem funduszy strukturalnych i Funduszu Spójności wprowadził istotne poprawki do aktów prawnych odnoszących się do zasad polityki rozwoju, a także wdrażania funduszy strukturalnych i polityki spójności (Dz.U. 2008 nr 216 poz. 1370). Pakiet ustawodawczy odnosił się przede wszystkim do postanowień dotyczących programowania nowych strategii rozwojowych, które miały wyznaczać nowe cele polityki.

Celem artykułu jest ukazanie zmian w polityce regionalnej w Polsce wywołanych przez kryzys gospodarczy. W ogólnym zarysie przedstawiono ewolucję polityki regionalnej w Polsce od 1990 roku, następnie zbadano wpływ kryzysu na poszczególne regiony oraz znaczenie funduszy strukturalnych dla ich gospodarki. Zasadniczą częścią pracy była analiza najistotniejszych zmian, jakie kryzys gospodarczy wywarł na kształtowanie polityki regionalnej w Polsce. Zakres przestrzenny analizy obejmuje regiony na poziomie województw w okresie globalnego spowolnienia gospodarczego, który w przypadku Polski przypadł na przełom 2008/2009 r. Dla lepszego ukazania zjawiska perspektywę czasową rozszerzono do lat 2007-2010.

\section{Rozwój Polityki Regionalnej w Polsce}

W roku 1990 w wyniku wprowadzania zmian ukierunkowanych na funkcjonowanie gospodarki rynkowej stworzono samorządy na szczeblu lokalnym, na poziomie poszczególnych miast oraz gmin. Dzięki tej transformacji organy lokalnej administracji publicznej zostały decydującymi podmiotami polityki rozwoju kraju. Jednak polityka ta prowadzona była na poziomie interregionalnym, a podstawowym jej podmiotem był rząd. Nie wprowadzono segmentu intraregionalnego, a w konsekwencji nie powołano samorządów regionalnych. Funkcje polityki intraregionalnej pełnił w pewnej części wojewoda, jako reprezentant rządu w terenie. Pierwsze lata po przekształceniach ustrojowych cechowały się niechęcią do prowadzenia aktywnej polityki regionalnej z uwagi na możliwości zakłócania przez nią warunków konkurencyjności, swoistych dla gospodarki rynkowej (Szlachta, Zaleski, 2010). Jedną z pierwszych form polityki regionalnej podejmowanej w Polsce w latach 80. i 90. XX 
wieku była interregionalna interwencja w obszarach, które były zagrożone wysokim bezrobociem o charakterze strukturalnym (MRR, 2011a).

Przełomowym etapem w ewolucji polityki regionalnej była perspektywa integracji z UE. W okresie przedakcesyjnym uruchomiono programy: PHARE (Poland and Hungary: Assistance for Restructuring their Economies), ISPA (Instrument for Structural Policies for Pre-Accession) oraz SAPARD (Special Programme for Agriculture and Rural Development), mające na celu wspieranie rozwoju regionalnego oraz przystosowanie potencjału administracyjnego w obszarze wspólnotowej polityki spójności. Zastrzeżeniem we wdrażaniu funduszy przedakcesyjnych w Polsce była konieczność stworzenia Wstępnego Narodowego Planu Rozwoju na lata 2000-2003, który był zgodny z zasadami programowania UE (MRR, 2011a).

1 stycznia 1999 roku weszła w życie reforma terytorialna, która stanowiła fundamentalną zmianę modelu polityki regionalnej w Polsce. Na jej mocy wprowadzono trójstopniową organizację terytorialną. W ramach zasad europejskiej polityki spójności województwa odpowiadały poziomowi NUTS2. Ten szczebel administracyjny wprowadził segment intraregionalny do krajowej polityki rozwoju, czyli samorządy województw, które odpowiadały za podejmowanie działań wewnątrz danego regionu. Przesunięto tym samym część kompetencji z segmentu interregionalnego na intraregionalny oraz wprowadzono nowe budżety województw. Przekształcenia te pozwoliły na tworzenie programów rozwoju społeczno-gospodarczego na szczeblu wojewódzkim, a tym samym umożliwiało prowadzenie polityki regionalnej w sposób kompleksowy (Szlachta, Zaleski, 2010).

Dokumentem regulującym ogólne zasady, kryteria oraz mechanizm polityki regionalnej kraju była Narodowa Strategia Rozwoju Regionalnego na lata 2001-2006. Istotnym zadaniem Strategii było przystosowanie modelu polskiej polityki regionalnej do wzorca i norm określonych przez UE. Było to ważne ze względu na postawiony przez UE warunek, po którego spełnieniu Polska miała możliwość korzystania z funduszy strukturalnych oraz Funduszu Spójności (Wojarska, 2013).

Następnym znaczącym punktem w ewolucji modelu polskiej polityki regionalnej było przystąpienie Polski do UE 1 maja 2004 roku. Integracja z UE pozwoliła na korzystanie z nowych środków finansowych w ramach polityki spójności. Zgodnie z jej wytycznymi, Polska uznała nowe zasady w zakresie: programowania, zarządzania, finansowania, monitoringu, ewaluacji, a także wyboru projektów. Istotnym elementem przejęcia rozwiązań polityki spójności UE było wprowadzenie zdecentralizowanego modelu gospodarowania funduszami strukturalnymi, który polegał na transferze dużego zakresu odpowiedzialności oraz środków finansowych regionom na poziomie NUTS2, czyli województwom (MRR, 2011a).

W latach 2004-2006 do Polski dotarł pierwszy pakiet funduszy strukturalnych obejmujący: Europejski Fundusz Rozwoju Regionalnego, Europejski Fundusz Społeczny, Europejski Fundusz Orientacji i Gwarancji Rolnej, Finansowy Instrument Wspierania Rybołówstwa oraz Fundusz Spójności (Michalak, 2010). Ich łączna wartość wynosiła 12,8 mld euro (w cenach stałych z 2004 roku). Podstawą do wdrażania polityki spójności w pierwszym okresie programowania był Narodowy Plan Rozwoju na lata 2004-2006, a także Podstawy Wsparcia Wspólnoty, będące wspólnym dokumentem rządu RP oraz KE (MRR, 2011a). W ramach funduszy strukturalnych i funduszy pomocowych funkcjonowały programy operacyjne służące 
wdrażaniu wyznaczonych celów polityki spójności. EFRR w latach 2004-2006 miał największy udział w całości wsparcia - 60,1\%. W ramach EFRR Zintegrowany Program Operacyjny Rozwoju Regionalnego wykorzystał około 22\% środków finansowych na lata 2004-2006 z europejskiej polityki spójności (Szlachta, Zaleski, 2010). Według analizy wykonanej na zlecenie Ministerstwa Rozwoju Regionalnego, regionalny rozkład wspólnotowych środków finansowych w pierwszych latach od wstąpienia Polski do UE nie wpłynął na zmniejszenie dysproporcji rozwojowych między regionami. Zauważono także braki w procedurach koordynujących wykorzystanie środków UE w ramach instrumentów polityki regionalnej (MRR, 2007).

W 2006 roku stworzono pierwszy dokument strategiczny odpowiadający polityce regionalnej państwa, była to Strategia Rozwoju Kraju na lata 2007-2015 (Grosse, 2009a). Określała ona jedne z ważniejszych priorytetów, a mianowicie rozwój regionalny oraz wzrost spójności terytorialnej (SRK na lata 2007-2015).

W okresie programowania na lata 2007-2013 do Polski trafił kolejny pakiet funduszy strukturalnych i FS o wartości około 59,5 mld euro (w cenach stałych z 2004 roku) (Szlachta, Zaleski, 2010). Zatwierdzony przez KE dokument Narodowe Strategiczne Ramy Odniesienia 2007-2013 wspierajace wzrost gospodarczy $i$ zatrudnienie, formułujący zasady podziału środków na określone dziedziny i regiony, zawierał dodatkowo 16 Regionalnych Programów Operacyjnych zarządzanych przez województwa. Dzięki temu rozwiązaniu część wsparcia skierowano bezpośrednio do regionów, wzmacniając przy tym proces decentralizacji systemu zarządzania funduszami polityki regionalnej w Polsce (Bedrunka, 2010). W ramach części Programu Operacyjnego Kapitał Ludzki oraz 16 RPO w latach 2007-2013 wykorzystano około 34\% środków europejskiej polityki spójności. Ponadto na lata 2007-2013 stworzono Program Operacyjny Rozwój Polski Wschodniej o charakterze makroregionalnym, skierowany do 5 najsłabszych strukturalnie województw (Szlachta, Zaleski, 2010). Chociaż jednym z zadań na okres programowania 2007-2013 miało być scentralizowanie zarządzania RPO, to o wyborze algorytmu podziału środków finansowych zadecydowano na poziomie centralnym (Bedrunka, 2010).

W 2009 roku, w celu ograniczenia liczby obowiązujących w Polsce strategii rozwoju oraz ich uporządkowania, Rada Ministrów wdrożyła Plan uporządkowania strategii rozwoju (Rospond-Bednarska, Kiełbasa, 2010), na podstawie którego w 2010 roku rząd RP przyjął Krajowa Strategię Rozwoju Regionalnego, zawierającą priorytety oraz działania w sektorze polityki regionalnej kraju do roku 2020 (MRR, 2011a).

\section{STOPIEŃ WRAŻLIWOŚCI REGIONÓW NA KRYZYS}

Określenie stopnia wrażliwości polskich regionów na wpływ negatywnych przemian w gospodarce, spowodowanych przez światowy kryzys finansowy, pozwoliło na ocenę przestrzennego zróżnicowania tego problemu. Współczesna gospodarka funkcjonuje w ramach różnego rodzaju powiązań, interakcji, zależności oraz współpracy. Zależności te obejmują zarówno gospodarkę na poziomie krajowym, jak i regionalnym. Postępujący proces 
globalizacji doprowadził do scalenia rynków krajowych i regionalnych, przez co zauważyć można natężenie skali konkurencji międzyregionalnej (Nazarczuk, 2013).

Analizie poddano regiony na poziomie województw w okresie najtrudniejszym dla polskiej gospodarki w czasie globalnego spowolnienia gospodarczego, czyli przełomu 2008 i 2009 r. (Ministerstwo Gospodarki, 2011). W celu lepszego ukazania zjawiska, badania rozszerzono na lata 2007-2010. Do scharakteryzowania stopnia wrażliwości regionów na wpływ kryzysu gospodarczego posłużył podstawowy miernik statystyczny, a mianowicie realne tempo wzrostu regionalnego (WDB) w cenach bazowych w układzie regionalnym. Przeanalizowano także sytuację na rynku pracy za pomocą wskaźników stopy bezrobocia oraz stopy zatrudnienia.

$\mathrm{Z}$ analizy opartej na wskaźnikach realnego tempa wzrostu regionalnego w cenach bazowych w latach 2007-2010 w układzie województw (tab. 1.) widać, które z obszarów były najbardziej wrażliwe na negatywne zjawiska z zewnątrz. Znaczny spadek wartości badanego wskaźnika w 2009 roku odnotowały województwa: kujawsko-pomorskie $(-1,0 \%)$, świętokrzyskie $(-0,7 \%)$, lubelskie $(-0,5 \%)$ i opolskie $(-0,1 \%)$. Natomiast najlepiej okres ten przeszły województwa: pomorskie $(4,1 \%)$, podlaskie $(3,4 \%)$, mazowieckie $(3,4 \%)$, małopolskie $(2,4 \%)$, wielkopolskie $(2,4 \%)$, warmińsko-mazurskie $(2,4 \%)$ oraz zachodniopomorskie $(2,3 \%)$.

Przyczynami dysproporcji badanego wskaźnika w województwach mogły być np. stopień otwartości regionów na wyminę międzynarodową, a także liczba oraz wielkość rynków zbytu (Nazarczuk, 2013).

Tab. 1. Realne tempo wzrostu regionalnego w cenach bazowych (zmiana procentowa w stosunku do roku poprzedniego)

\begin{tabular}{|l|c|c|c|c|}
\hline \multirow{2}{*}{ Województwa } & \multicolumn{4}{c|}{ Lata } \\
\cline { 2 - 5 } & 2007 & 2008 & 2009 & 2010 \\
\hline dolnośląskie & 9,0 & 5,0 & 1,6 & 4,9 \\
\hline kujawsko-pomorskie & 6,5 & 4,1 & $-1,0$ & 2,8 \\
\hline lubelskie & 5,3 & 6,5 & $-0,5$ & 3,7 \\
\hline lubuskie & 5,5 & 5,5 & 0,4 & 2,6 \\
\hline łódzkie & 6,1 & 6,1 & 0,7 & 3,8 \\
\hline małopolskie & 4,6 & 6,7 & 2,4 & 2,5 \\
\hline mazowieckie & 8,2 & 5,3 & 3,4 & 5,1 \\
\hline opolskie & 7,3 & 0,7 & $-0,1$ & 2,0 \\
\hline podkarpackie & 4,6 & 6,8 & 1,6 & 3,2 \\
\hline podlaskie & 4,6 & 2,8 & 3,4 & 1,7 \\
\hline pomorskie & 6,7 & 2,6 & 4,1 & 3,5 \\
\hline śląskie & 8,9 & 6,8 & 0,6 & 4,3 \\
\hline świętokrzyskie & 6,6 & 6,2 & $-0,7$ & 2,3 \\
\hline warmińsko-mazurskie & 3,4 & 4,5 & 2,4 & 3,0 \\
\hline wielkopolskie & 4,9 & 3,8 & 2,4 & 2,7 \\
\hline zachodniopomorskie & 2,9 & 2,8 & 2,3 & 3,2 \\
\hline
\end{tabular}

Źródło: opracowanie własne na podstawie danych Eurostat 
Analizowany okres 2007-2010 trudny był także dla polskiego rynku pracy, głównie ze względu na spowolnienie wzrostu gospodarczego. Stopa bezrobocia zmniejszała się sukcesywnie do 2008, natomiast w 2009 roku wartość współczynnika wzrosła (MRR, 2011b). Opierając analizę na wskaźniku stopy bezrobocia w przekroju terytorialnym (tab. 2.), można wykazać, że w 2009 roku stopa bezrobocia wzrosła w porównaniu z rokiem wcześniejszym we wszystkich województwach, z wyjątkiem województwa mazowieckiego, gdzie wartość wskaźnika utrzymała się na takim samym poziomie. Istotny wzrost bezrobocia w tym okresie odnotowały województwa: opolskie (3,4 p.p.), lubuskie (3,1 p.p.), świętokrzyskie (2,0 p.p.), podkarpackie (1,9 p.p.), małopolskie (1,7 p.p.), wielkopolskie (1,4 p.p.), warmińsko-mazurskie (1,1 p.p.) i dolnośląskie (1,0 p.p.). Warto zauważyć, że wartość wskaźnika w niektórych regionach w roku 2010 była niższa niż w roku 2007, taką sytuację zaobserwowano w województwach: mazowieckim, warmińsko-mazurskim, kujawsko-pomorskim, dolnośląskim i pomorskim, czyli tych o silnie rozwiniętej gospodarce.

Tab. 2. Stopa bezrobocia [\%] (15 lat i więcej)

\begin{tabular}{|l|r|c|r|r|}
\hline \multirow{2}{*}{ Województwa } & \multicolumn{4}{c|}{ Lata } \\
\cline { 2 - 5 } & 2007 & 2008 & \multicolumn{1}{c|}{2009} & 2010 \\
\hline dolnośląskie & 12,7 & 9,1 & 10,1 & 11,3 \\
\hline kujawsko-pomorskie & 11,3 & 9,1 & 10,4 & 10,6 \\
\hline lubelskie & 9,5 & 8,8 & 9,7 & 9,9 \\
\hline lubuskie & 9,8 & 6,5 & 9,6 & 10,5 \\
\hline łódzkie & 9,3 & 6,7 & 7,6 & 9,3 \\
\hline małopolskie & 8,5 & 6,2 & 7,9 & 9,1 \\
\hline mazowieckie & 9,1 & 6,0 & 6,0 & 7,4 \\
\hline opolskie & 9,4 & 6,5 & 9,9 & 9,6 \\
\hline podkarpackie & 9,6 & 8,2 & 10,1 & 11,7 \\
\hline podlaskie & 8,9 & 6,4 & 7,1 & 10,2 \\
\hline pomorskie & 9,5 & 5,5 & 6,4 & 9,3 \\
\hline śląskie & 8,1 & 6,6 & 6,7 & 9,1 \\
\hline świętokrzyskie & 12,1 & 8,8 & 10,8 & 12,0 \\
\hline warmińsko-mazurskie & 10,5 & 7,4 & 8,5 & 9,6 \\
\hline wielkopolskie & 8,3 & 6,1 & 7,5 & 8,8 \\
\hline zachodniopomorskie & 11,5 & 9,5 & 10,4 & 12,3 \\
\hline
\end{tabular}

Źródło: opracowanie własne na podstawie danych Eurostat

Równie niekorzystnie wygląda sytuacja w zakresie procentowego wskaźnika zatrudnienia według regionów (ryc. 1.). Najbardziej wrażliwe na wahania koniunktury gospodarczej były województwa, gdzie w 2009 roku procentowy wskaźnik zatrudnienia zmniejszył się w porównaniu z rokiem wcześniejszym: świętokrzyskie ( $-1,5$ p.p.), małopolskie ( $-0,8$ p.p.), łódzkie ( $-0,7$ p.p.), lubuskie ( $-0,7$ p.p.), pomorskie ( $-0,6$ p.p.) oraz lubelskie $(-0,5$ p.p.). $\mathrm{W}$ województwie podlaskim wartość wskaźnika w analizowanym okresie nie zmieniła się, natomiast w pozostałych województwach była dodatnia. Warto zaznaczyć, że w województwach śląskim i kujawsko-pomorskim wartość ta wynosiła 1,2 p. 


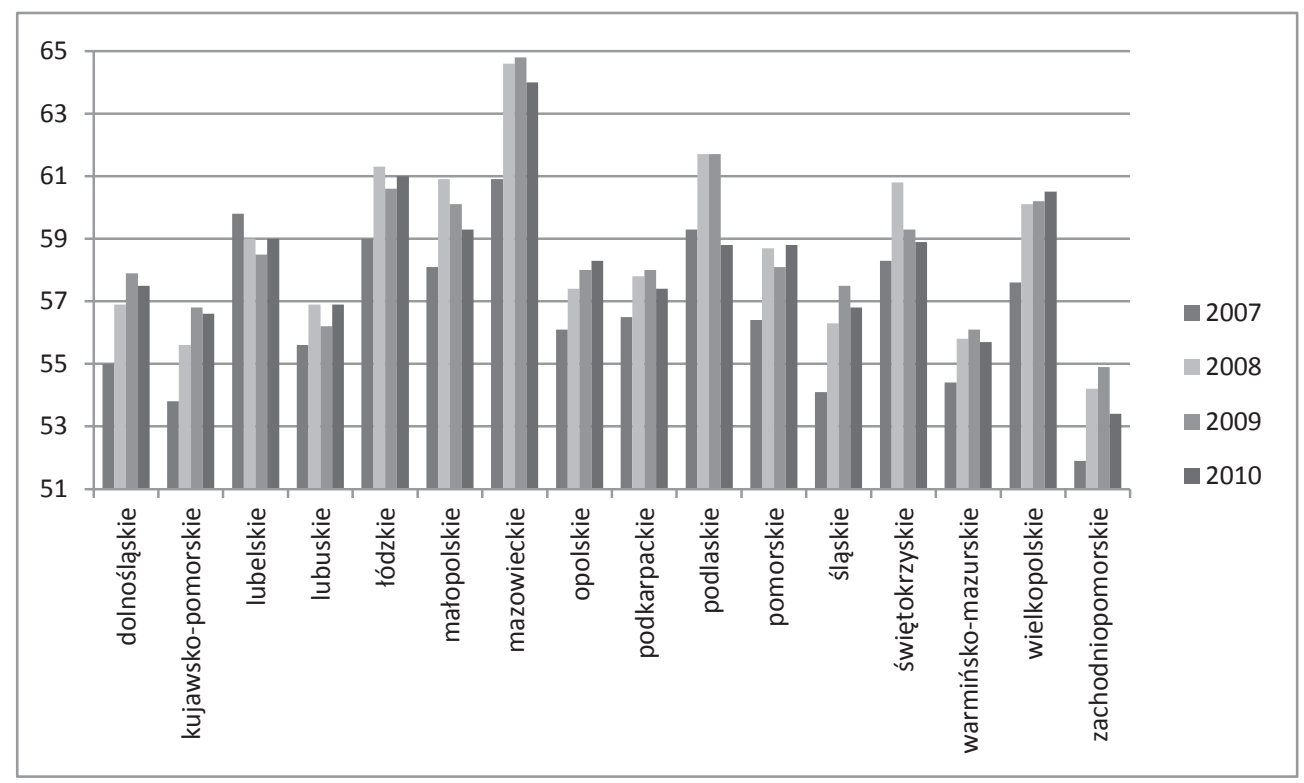

Ryc. 1. Procentowy wskaźnik zatrudnienia według regionów (15-64 lat)

Źródło: opracowanie własne na podstawie danych GUS

Badania dotyczące wrażliwości regionów na negatywne zjawiska kryzysu gospodarczego w latach 2008-2009 wykazały, że kryzys miał większy wpływ na rynki pracy w regionach najsłabszych pod względem realnego tempa wzrostu regionalnego, co najbardziej jest widoczne w województwach: świętokrzyskim, lubuskim, lubelskim i łódzkim.

W analizie ważna była zmiana wartości badanych wskaźników, która pozwoliła na ocenę sytuacji gospodarki w poszczególnych regionach w okresie kryzysu. Wpływ kryzysu na poszczególne regiony w Polsce jest zróżnicowany, przede wszystkim ze względu na dysproporcję liczby branż najbardziej podatnych na spowolnienie gospodarcze w poszczególnych województwach, a także osłabienie głównych czynników decydujących o ich rozwoju gospodarczym (Miszczak, 2010). Najsilniejszą pozycję mają regiony, które charakteryzują się wysokim stopniem innowacyjności oraz rozwojem gospodarki opartej na wiedzy. Nierówny rozkład możliwości tworzenia i dostosowania innowacyjnych rozwiązań pogłębia dysproporcje w poziomie rozwoju regionów (Nazarczuk, 2013).

\section{WPEYW FUNDUSZY EUROPEJSKICH NA GOSPODARKĘ POLSKICH REGIONÓW}

Polityka regionalna UE jest finansowana za pomocą 2 funduszy strukturalnych: Europejskiego Funduszu Rozwoju Regionalnego (EFRR) i Europejskiego Funduszu Społecznego (EFS), a także z Funduszu Spójności (FS) (Michalak, 2010). Wśród korzyści płynących z członkostwa Polski w UE najczęściej wymienia się transfery pieniężne, które 
możemy otrzymać z budżetu Wspólnoty. Wartość środków finansowych wykazanych we wnioskach beneficjentów o płatność w 2011 roku uzyskała wartość ponad 100 mln złotych, natomiast wartość środków dofinansowania przez UE wyniosła około 25 mld euro. Według sprawozdania z realizacji NSRO na lata 2007-2013, takie kwoty w znacznym stopniu przyczyniły się do ograniczenia negatywnych skutków kryzysu gospodarczego (MRR, 2012a). Wpływ polityki spójności na rozwój społeczno-gospodarczy Polski według MRR jest jak najbardziej pozytywny. Fundusze europejskie w znacznym stopniu oddziałują na rozwój gospodarczy, rynek pracy, a także aktywność inwestycyjną w Polsce (tab. 3.). Środki z funduszy strukturalnych na okres programowania 2007-2013 stanowią średnio około 2,4\% PKB w Polsce. Przyczyniają się również do utrzymania zewnętrznej oraz wewnętrznej równowagi gospodarki. Według przeprowadzonych badań wpływ funduszy europejskich na tempo wzrostu PKB w 2011 roku przyczynił się do zwiększenia o około 0,5-0,9 p.p. w porównaniu ze scenariuszem bez funduszy UE. Według szacunków oddziaływanie polityki spójności na rozwój Polski ma być jeszcze bardziej efektywne w latach 2013-2015 (MRR, 2013).

Tab. 3. Planowany przydział wsparcia w ramach polityki strukturalnej UE jako \% PKB w Polsce

\begin{tabular}{|c|c|c|c|c|c|c|c|}
\hline 2007 & 2008 & 2009 & 2010 & 2011 & 2012 & 2013 & Średnia na lata 2007-2013 \\
\hline 2,7 & 2,6 & 2,5 & 2,4 & 2,4 & 2,3 & 2,3 & 2,4 \\
\hline
\end{tabular}

Źródło: opracowanie własne na podstawie Kamps, Leiner-Killinger, Martin (2009)

W okresie programowania na lata 2007-2013 można wyróżnić dwa wzorce podejścia rozwojowego: sektorowe oraz terytorialne. Polityka opierająca się na podejściu terytorialnym zorientowana jest na aktywizację potencjału na podstawie istniejących zasobów endogenicznych. Natomiast podejście sektorowe charakteryzuje się brakiem interdyscyplinarności w działaniach, czego efektem jest nasilenie polaryzacji oraz duże rozproszenie środków finansowych (MRR, 2012b). Na poziomie regionalnym proces konwergencji jest nierównomierny, przede wszystkim ze względu na zróżnicowane tempo wzrostu regionów. Duże znaczenie mają także ich wewnętrzne potencjały oraz dostosowane do nich struktury funduszy. Różnice te prowadzą do pogłębiania się dysproporcji na poziomie rozwoju między regionami. Najdynamiczniej rozwijają się województwa z dużymi ośrodkami miejskimi, będącymi zarazem swoistymi centrami rozwoju (np. mazowieckie, dolnośląskie czy pomorskie). Natomiast województwa Polski wschodniej, tj. warmińsko-mazurskie, podlaskie, lubelskie, podkarpackie, wykazują najmniejsze tempo rozwoju (Tomaszewski, Zaleski, Zembaty, 2011). Według MRR fundusze unijne mogą przyczynić się do zniwelowania polaryzacji regionalnej ze względu na silniejsze oddziaływanie funduszy w województwach słabszych strukturalnie oraz transfer największych nakładów kierowanych do tych regionów w przeliczeniu na jednego mieszkańca.

Badanie wpływu funduszy europejskich na dynamikę PKB w cenach bieżących średnio w latach 2004-2015 na poziomie regionalnym określane jest we wszystkich województwach jako pozytywne, jednak dość spolaryzowane (MRR, 2013). Najmniejszą skalę oddziaływania funduszy w latach 2004-2012 zaobserwowano w województwach: dolnośląskim, wielkopolskim oraz małopolskim, czyli w tych, które charakteryzowały się stosunkowo wysokim 
stopniem rozwoju. Natomiast największy wpływ zaobserwowano w województwach Polski wschodniej: warmińsko-mazurskim, podkarpackim i świętokrzyskim. Wyniki te pokrywają się także z liczbą wniosków o dofinansowanie według programów operacyjnych na lata 2007 2013 na jednego mieszkańca (ryc. 2.), gdy najwyższy wskaźnik zaobserwowano w województwach: warmińsko-mazurskim, lubelskim, podlaskim, łódzkim, lubuskim, świętokrzyskim i podkarpackim. Według MRR większe oddziaływanie wystąpiło również w województwie mazowieckim, przede wszystkim ze względu na jego charakter oraz wysoki poziom finansowania i absorpcji funduszy. Przewiduje się, że w dłuższej perspektywie środki z funduszy unijnych najsilniej będą oddziaływać na rozwój Polski wschodniej. Analiza wpływu polityki spójności na rozwój społeczno-gospodarczy Polski w latach 2004-2015 w świetle wyników badań makroekonomicznych wykazała duże zróżnicowanie w nakładach inwestycyjnych według województw. Wpływ środków z funduszy europejskich na nakłady inwestycyjne największe znaczenie ma w województwach: warmińsko-mazurskim, lubelskim, świętokrzyskim oraz podkarpackim. Natomiast najmniejszy wpływ odnotowują: mazowieckie, dolnośląskie, wielkopolskie i małopolskie. Podobnie wygląda sytuacja na rynku pracy - szacuje się, że zmiany będą pozytywne, jednak zachodzić będą powoli. Najsilniejsze oddziaływanie funduszy na wskaźnik zatrudnienia średnio w latach 2004-2015 odnotowany zostanie w województwach: zachodniopomorskim, lubuskim, warmińsko-mazurskim oraz podkarpackim, przy czym skala wpływu będzie bardzo zróżnicowana, natomiast najmniejszy wpływ wykażą województwa: wielkopolskie, opolskie oraz małopolskie. Jeśli chodzi o stopę bezrobocia, to fundusze oddziaływać będą najsilniej w województwach: zachodniopomorskim, lubuskim i warmińsko-mazurskim, a najsłabiej w województwie wielkopolskim (MRR, 2013).

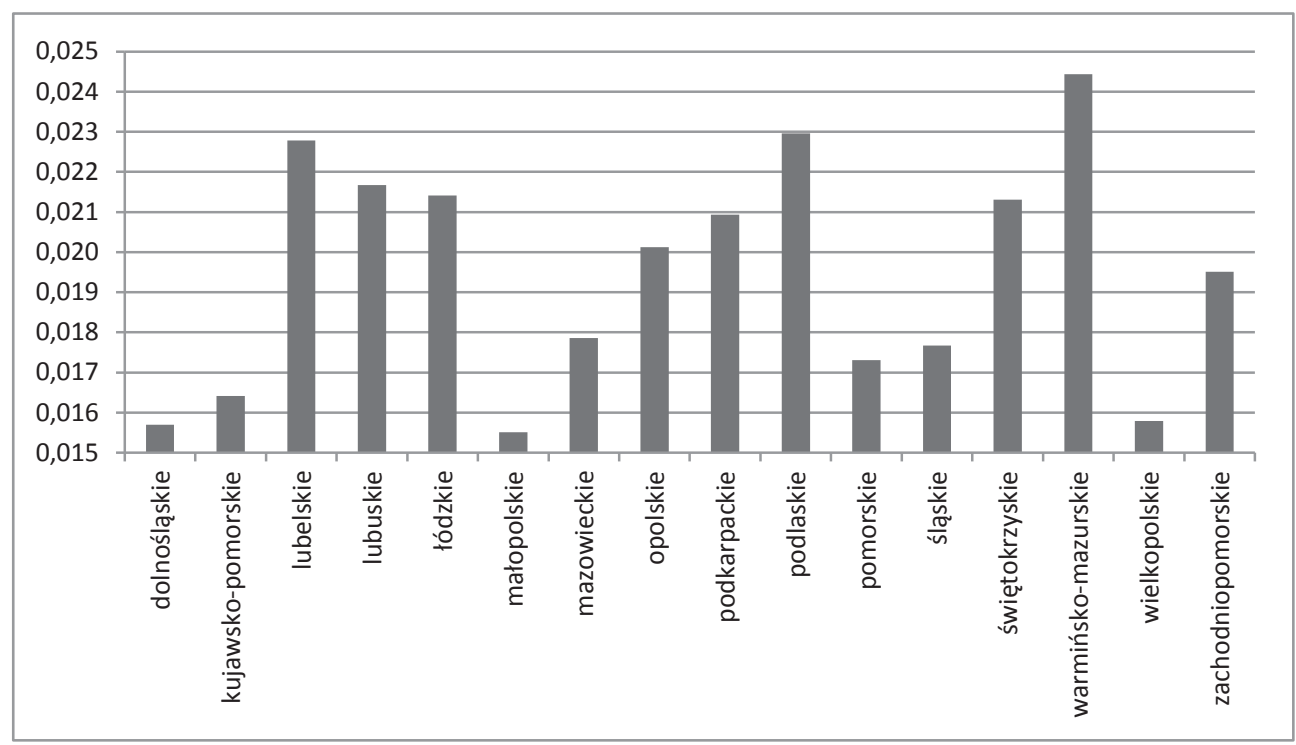

Ryc. 2. Liczba wniosków o dofinansowanie według programów operacyjnych na lata 2007-2013 na jednego mieszkańca (stan na 31.06.2013)

Źródło: opracowanie własne na podstawie danych GUS 
Dzięki środkom z funduszy strukturalnych i FS występują korzystne zmiany strukturalne, jednak w perspektywie regionalnej są one dosyć nierównomierne. Duży problem w obecnym systemie zarządzania oraz wprowadzania polityki spójności UE stanowi brak efektywnego zharmonizowania działań w ramach krajowych programów operacyjnych z programami regionalnymi (MRR, 2012b). Wykorzystanie funduszy unijnych może sprzyjać pogłębianiu dysproporcji międzyregionalnych ze względu na sposób zarządzania nimi oraz ich wydatkowania. Kolejnym problemem jest założenie, że najważniejszym celem w wykorzystaniu funduszy unijnych jest maksymalizacja ich wydatkowania. Polska jest jednym z największych beneficjentów funduszy strukturalnych na okres programowania 2007-2013, dlatego też efekty w prowadzeniu polityki regionalnej oraz wykorzystaniu środków z UE mogą być miernikiem poprawności prowadzenia polityki spójności UE (Tkaczyński, 2012).

\section{Zmiany W POlityce Regionalnej W Polsce W WARUnKach} KRYZYSU GOSPODARCZEGO

Zmiany w polityce regionalnej na skutek kryzysu gospodarczego w nowo przyjętych państwach UE były dosyć ograniczone, przede wszystkim z powodu wcześniej uzgodnionych ram polityki spójności na okres 2007-2013. Dodatkowym ograniczeniem było również to, że większość działań polegających na poprawie warunków, na podstawie których prowadzona jest działalność gospodarcza, ukierunkowana jest na sektor centralny, a nie regionalny. Obowiązującą formą prowadzenia polityki regionalnej w Polsce jest model terytorialny, który zakłada skupienie się na potencjale endogenicznym wszystkich województw, oraz szczegółowych interwencji skierowanych do wyselekcjonowanych regionów. Ważnym aspektem jest również stworzenie zintegrowanego systemu interwencji regionalnych na wszystkich poziomach administracji samorządowej w celu prowadzenia kompleksowej polityki regionalnej, w którą ingerować mogą wszystkie podmioty publiczne (EoRPA, 2009).

W odpowiedzi na plan KE dotyczący przeciwdziałania negatywnym skutkom kryzysu polski rząd opracował Plan Stabilności i Rozwoju. Wzmocnienie gospodarki wobec światowego kryzysu finansowego. Priorytetem Planu miało być ratowanie krajowego systemu finansów publicznych przed potencjalnymi trudnościami w finansowaniu kosztów zadłużenia. Celem rządu było także zatrzymanie zagranicznych inwestycji oraz zmniejszenie skutków kryzysu walutowego (Grosse, 2009b). Najważniejsze znaczenie miała stabilizacja sytuacji makroekonomicznej, dotycząca przede wszystkim wysokości długu publicznego oraz deficytu w budżecie. Dla zabezpieczenia sytuacji na krajowym rynku finansowym Plan przewidywał zwiększenie limitu przeznaczonego na poręczenia i gwarancje Skarbu Państwa o 40 mld złotych oraz wzmocnienie systemu gwarancji i poręczeń kredytowych dla małych i średnich przedsiębiorstw do poziomu 20 mld złotych. Kluczowym założeniem dla polityki regionalnej stał się zapis dotyczący przyspieszenia inwestycji współfinansowanych ze środków UE. Zakładał on stworzenie warunków zwiększenia wydatkowania środków kwalifikowanych 
z poziomu 10 mld złotych do 16,8 mld złotych, zatwierdzonych przez KE do końca 2009 roku (Plan Stabilności i Rozwoju..., 2009).

Wszystkie województwa w Polsce korzystają z pomocy finansowej w ramach polityki regionalnej. Alokacja większych środków finansowych RPO w ramach funduszy strukturalnych oraz krajowych kontraktów regionalnych dotyczy regionów słabszych strukturalnie. KSRR zakłada zmniejszenie różnic oraz zwiększenie efektywności działań w zakresie polityki regionalnej poprzez pierwszeństwo w wykorzystaniu zróżnicowanych możliwości rozwoju najbardziej konkurencyjnych sektorów i ośrodków, co w dłuższej perspektywie ma wyrównać uzyskane w ten sposób korzyści, jakimi są dostęp do infrastruktury telekomunikacyjnej i transportowej, szanse kształcenia czy integracja społeczna (MRR, 2011b).

W styczniu 2009 roku MRR stworzyło Program szybkiego wdrażania programów finansowanych z funduszy UE. Główne założenia programu to: stosowanie uproszczonych procedur wdrożeniowych na różnych poziomach administracji samorządowej, ulepszenie korelacji pomiędzy funduszami strukturalnymi i aparatem finansów publicznych oraz wykorzystanie możliwości wynikających z przyjęcia pakietu antykryzysowego przez KE w 2008 roku (Tarnawska, 2011). Pakiet ten zakładał:

- zwiększenie zaliczki w ramach EFRR i EFS o dodatkowe 2\% w stosunku do alokacji wypłacanej państwom członkowskim przez KE w 2009 roku;

- możliwość składania wniosków płatniczych dotyczących dużych projektów, czyli takich, których wartość przekracza 25 mln euro w przypadku projektów środowiskowych oraz 50 mln euro w przypadku innych dziedzin (Rozporządzenie Rady [WE] nr 1083/2006) przed oficjalną decyzją KE w sprawie zakwalifikowania tych projektów do współfinansowania;

- wydłużenie okresu kwalifikowania wydatków dla programów z okresu 2000-2006 poza koniec 2008 roku;

- możliwość rozliczania na zasadach ryczałtu kosztów ogólnych w programach, które są współfinansowanie z EFRR;

- rozszerzenie dla beneficjentów (np. dla władz samorządowych oraz małych i średnich przedsiębiorstw) zakresu możliwych zaliczek do 100\% wartości projektu (Plan Stabilności i Rozwoju..., 2009).

Szczegółowymi założeniami do Programu szybkiego wdrażania... były: konkurencja między programami operacyjnymi, na podstawie której najlepsze dostawałyby dodatkowe profity finansowe $\mathrm{z}$ narodowej rezerwy wykonania; modyfikacje w transferach środków finansowych pomiędzy RPO; standaryzacja czasu przewidzianego na procesy o kluczowym znaczeniu dla wdrażania projektów; przekształcenia w procedurach korzystania z państwowej rezerwy budżetowej na opłacanie projektów w ramach programów operacyjnych; wsparcie aparatu monitorowania przygotowania dużych projektów (Tarnawska, 2011).

Celem polityki regionalnej stało się także wyselekcjonowanie obszarów interwencji strategicznej w obrębie całego państwa oraz wprowadzenie indywidualnych mechanizmów pozwalających na dodatkowe ich wsparcie. Kolejnym założeniem jest poprawa konkurencyjności obszarów miejskich poprzez stworzenie związków aglomeracyjnych prowadzących do zwiększenia możliwości współpracy z innymi jednostkami terytorialnymi. Korzystne zmiany w warunkach prowadzenia działalności gospodarczej są priorytetem w wykorzystaniu 
dofinansowania w ramach funduszy unijnych. Choć w okresie programowania na lata 2007 2013 RPO mają już większe znaczenie, to ich finansowanie jest w dalszym ciągu dużo niższe w porównaniu z krajowymi i sektorowymi programami operacyjnymi (EoRPA 09/2, 2009).

\section{Podsumowanie}

W większości krajów odpowiedzią na negatywne skutki kryzysu gospodarczego było wprowadzenie narzędzi polityki gospodarczej na poziomie krajowym i międzynarodowym (Tarnawska, 2011).

Fundusze strukturalne, które są jednym z podstawowych narzędzi finansowania polityki regionalnej w Polsce, nie są przeznaczone do rozwiązywania problemów bieżących. Ich zasadniczą rolą jest osiąganie założonych celów długookresowych. W ramach polityki regionalnej w okresie kryzysu mogą być one traktowane jako uzupełnienie części inwestycji prywatnych. Dodatkowo EFS traktowany jest przez KE jako instrument pomocny w łagodzeniu negatywnego wpływu kryzysu na rozwój regionalny (Żuber, 2010). Dlatego można powiedzieć, ze polska polityka regionalna nie stanowi narzędzia do walki z negatywnymi skutkami kryzysu gospodarczego, jednak środki, które są przeznaczane na finansowanie tej polityki, stanowią wysoką pozycję w budżecie kraju (Tarnawska, 2011).

Zmiany charakteru i obszaru działania polityki regionalnej w Polsce na przestrzeni ostatnich lat regulowane były przez następujące ustawy stanowiące podstawę do wprowadzenia programowania rozwoju społeczno-gospodarczego na poziomie regionalnym:

- Ustawa z dnia 12 maja 2000 roku o zasadach wspierania rozwoju regionalnego (Dz.U. $2000 \mathrm{Nr} 48$, poz. 550);

- Ustawa z dnia 20 kwietnia 2004 roku o Narodowym Planie Rozwoju (Dz.U. 2004 Nr 116, poz. 1206);

- Ustawa z dnia 12 grudnia 2006 roku o zasadach prowadzenia polityki rozwoju (Dz.U. $2006 \mathrm{Nr} 227$, poz. 1658);

- Ustawa z dnia 8 listopada 2008 roku o zmianie niektórych ustaw w związku z wdrażaniem funduszy strukturalnych i Funduszu Spójności (Dz.U. 2008 Nr 216, poz. 1370).

Obecnie nie ma warunków do kompleksowego przeprogramowania polityki regionalnej w celu zorientowania jej na przeciwdziałanie negatywnym skutkom kryzysu. Działania takie mogłyby być nawet szkodliwe dla dalszego rozwoju z powodu specyfiki wyznaczanych przez politykę regionalną celów. Oddziaływanie światowego kryzysu gospodarczego na polskie regiony może stymulować zwiększenie skuteczności wydatkowania funduszy strukturalnych UE oraz przyspieszać ich realizację, a co za tym idzie - zwiększać efektywność obsługi administracyjnej. Wpływ kryzysu spowodował pewne modyfikacje w polityce regionalnej, które mogą oddziaływać korzystnie na sytuację gospodarczą kraju i regionów, a także na kształtowanie samej polityki regionalnej, co w przełożeniu na dalszą perspektywę czasową może zwiększyć efektywność tej polityki. 
W celu osłabienia zagrożeń spowodowanych przez wpływ światowego kryzysu na rozwój polskich regionów należałoby się skupić na stworzeniu jak najbardziej korzystnych warunków do rozwoju przedsiębiorczości oraz uproszczeniu dostępu do funduszy strukturalnych UE, postrzeganych jako narzędzie tworzenia nowych miejsc pracy.

\section{Literatura \\ References}

Bedrunka, K. (2010). Analiza algorytmów podziału środków europejskich pomiędzy regiony i ich skutków dla polityki regionalnej na przykładzie województwa opolskiego. W: K. Malik (red.). Polityka rozwoju regionu. Koncepcja. Procedury administracyjne. Finansowanie. Opole: Politechnika Opolska, [etc.], Kraków: Wydawnictwo Naukowe „Akapit”, 155-179.

Czekaj, J. (2010). Wpływ światowego kryzysu gospodarczego na polską gospodarkę. W: G.W. Kołodko (red.). Globalizacja, kryzys i co dalej?. Warszawa: Potext sp. z o.o., 189-209.

Davies, S., Kah, S., Woods, Ch. (2010). Regional Dimensions of the Financial and Economic Crisis. EuropeanPolicyResearchPaper, No.70.February2010.Pozyskanozhttp://www.eprc.strath.ac.uk/ eprc/documents/PDF_files/EPRP_70_RegionalDimensionsoftheFinancialandEconomicCrisis. pdf.

Dudziak, M. (2009). Instrumenty finansowe Unii Europejskiej w Polsce realną szansą rozwoju. W: W. Sługocki (red.). Polityka regionalna w Polsce jako przestrzeń aktywności samorzadu terytorialnego. Warszawa: Dom Wydawniczy ELIPSA, 34-40.

EoRPA 09/2 (2009). Polityka regionalna $w$ warunkach kryzysu. Najnowsze zmiany $w$ polityce regionalnej $w$ UE $i$ w Norwegii. Pozyskano z http://www.mir.gov.pl/rozwoj_regionalny/Ewaluacja_i_ analizy/Raporty_o_rozwoju/EoRPA/Documents/09_02.pdf.

Grosse, T.G. (2009a). Cele i zasady polityki regionalnej państwa. Ekspertyza dla Ministerstwa Rozwoju Regionalnego na temat Krajowej Strategii Rozwoju Regionalnego. Pozyskano z http:// www.mrr.gov.pl/rozwoj_regionalny/poziom_regionalny/ekspertyzy/Documents/Grosse_ekspertyza_Cele\%20i_zasady_MRR_02042009_1.pdf.

Grosse, T.G. (2009b). Program stabilności czy rozwoju? Analizy i Opinie nr 89, Instytut Spraw Publicznych. Pozyskanozhttp://www.isp.org.pl/uploads/analyses/2696241100814232001229599724. pdf.

Kamps, C., Leiner-Killinger, N., Martin, R. (2009). The Cyclical Impact of UE Cohesion Policy in Fast Growing UE Countries, Intereconomics, January-February, 25. Pozyskano z http://www. econstor.eu/bitstream/10419/66182/1/727018620.pdf.

Krajowa Strategia Rozwoju Regionalnego 2010-2020. Pozyskano z http://www.mir.gov.pl/rozwoj_regionalny/polityka_regionalna/ksrr_2010_2020/strony/default.aspx.

Michalak, A. (2010). Środki finansowe Unii Europejskiej jako wsparcie dla rozwoju społeczno-gospodarczego jednostek samorządu terytorialnego. W: K. Malik (red.). Polityka rozwoju regionu, Koncepcja Procedury administracyjne Finansowanie. Opole: Polityka Opolska, [etc.], Kraków: Wydawnictwo Naukowe „Akapit”, 137-154.

Ministerstwo Gospodarki (2011). Koniunktura gospodarcza $w$ wybranych krajach $w$ okresie kryzysu finansowego, 41-43. Pozyskano z http://www.mg.gov.pl/files/upload/8441/MG_DAP_ Koniunktura_gosp._w_wybranych_krajach_w_okresie_kryzysu\%20_fin.pdf

Ministerstwo Rozwoju Regionalnego (2013). Wptyw polityki spójności na rozwój społeczno gospodarczy Polski w latach 2004-2015 w świetle wyników badań makroekonomicznych. Pozyskano z https://www.mrr.gov.pl/rozwoj_regionalny/Ewaluacja_i_analizy/Oddzialywanie_makroekonomiczne/Documents/material_informacyjny.pdf. 
Ministerstwo Rozwoju Regionalnego (2012a). Sprawozdanie z realizacji Narodowych Strategicznych Ram Odniesienia na lata 2007-2013. Pozyskano z http://www.mir.gov.pl/fundusze/fundusze_europejskie/wykorzystanie_funduszy/sprawozdania_roczne/Documents/ Sprawozdanizrealizacjiw2011rNSROnalata713_01102012.pdf.

Ministerstwo Rozwoju Regionalnego (2012b). Ocena prób zastosowania podejścia zintegrowanego $w$ Polsce $i$ wybranych krajach $w$ okresie programowania 2007-2013 oraz wnioski $w$ kontekście obecnego i przyszłego okresu programowania. Pozyskano z http://www.ewaluacja.gov.pl/ Wyniki/Documents/Ocena_prob_zastosowania_podesjcia_zintegrowanego_w_Polsce_oraz_ wnioski_6022013.pdf.

Ministerstwo Rozwoju Regionalnego (2011a). Polityka regionalna w Polsce. Pozyskano z http://www. mir.gov.pl/konferencje/eic2011/pl/Documents/Polityka_regionalna_w_Polsce.pdf.

Ministerstwo Rozwoju Regionalnego (2011b). Raport Polska 2011. Gospodarka - Spoleczeństwo - Regiony. Pozyskano z http://orka.sejm.gov.pl/Druki7ka.nsf/0/F7866CE71F703210C12579 6100355F9E/\$File/59.pdf.

Ministerstwo Rozwoju Regionalnego (2007). Raport o rozwoju i polityce regionalnej. Pozyskano z http://www.funduszeeuropejskie.gov.pl/dzialaniapromocyjne/PI/Documents/wydawnictwa/raportrozwoj_druk.pdf.

Miszczak, K. (2010). Regionalny wymiar światowego kryzysu w Polsce. Biblioteka Regionalisty, tom 10/2010. Wrocław: Uniwersytet Ekonomiczny, 137-151. Pozyskano z http://www.depot.ceon. $\mathrm{pl} /$ bitstream/handle/123456789/688/Regionalny\%20wymiar\%20\%C5\%9Bwiatowego\%20kryzysu\%20w\%20Polsce_1.pdf? sequence $=1$.

Nazarczuk, J.M. (2013). Wpływ światowego kryzysu finansowego na gospodarkę Polski i jej regionów. W: R. Kisiel, M. Wojarska (red.). Wybrane aspekty rozwoju regionalnego, Olsztyn: Fundacja „Wspieranie i Promocja Przedsiębiorczości na Warmii i Mazurach”, 75-89. Pozyskano z http:// www.uwm.edu.pl/wne/katedry/kpgir/files/mono_wybrane-aspekty2013_tresc.pdf.

Plan Stabilności i Rozwoju. Wzmocnienie gospodarki wobec światowego kryzysu finansowego (2009). Pozyskano z http://orka.sejm.gov.pl/Druki6ka.nsf/wgdruku/1709/\$file/1709.pdf.

Rospond-Bednarska, D., Kiełbasa, K. (2010). Nowa koncepcja polityki regionalnej państwa jako jedno z uwarunkowań rozwoju regionu. W: K. Malik (red.). Polityka rozwoju regionu, Koncepcja Procedury administracyjne Finansowanie. Opole: Politechnika Opolska, [etc.], Kraków: Wydawnictwo Naukowe „Akapit”, 39-54.

Rozporządzenie Rady (WE) nr 1083/2006 z dnia 11 lipca 2006 r. ustanawiające przepisy ogólne dotyczące Europejskiego Funduszu Rozwoju Regionalnego, Europejskiego Funduszu Społecznego oraz Funduszu Spójności i uchylające rozporządzenie (WE) nr 1260/1999. Pozyskano z http:// eur-lex.europa.eu/LexUriServ/LexUriServ.do?uri=OJ:L:2006:210:0025:0078:PL:PDF.

Szlachta, J., Zaleski, J. (2010). Kierunki polityki regionalnej w Polsce do roku 2020. Gospodarka Narodowa, Nr 10/2010, 37-56. Pozyskano z http://gospodarkanarodowa.sgh.waw.pl/p/gospodarka_narodowa_2010_10_02.pdf.

Strategia Rozwoju Kraju na lata 2007-2015. Pozyskano z http://www.mir.gov.pl/rozwoj_regionalny/ Polityka_rozwoju/SRK/Documents/SRK_2007_2015.pdf.

Tarnawska, K. (2011). Analiza przydatności polityki regionalnej UE w przeciwdziałaniu negatywnym skutkom kryzysu w krótkim i długim okresie. W: Z. Dach (red.). Polityka makroekonomiczna w warunkach kryzysu i jej wptyw na gospodarkę. Warszawa: Wolters Kluwer Polska Sp. z o.o., $138-164$.

Tkaczyński, J.W. (2012). Fundusze unijne dla Polski - czy wszystko się udało? Pozyskano z http:// ec.europa.eu/polska/news/opinie/121010_fundusze_unijne_dla_polski_pl.htm.

Tomaszewski, P., Zaleski, J., Zembaty, M. (2011). Oczekiwane efekty realizacji polityki spójności Unii Europejskiej na poziomie regionalnym w Polsce. Studia Regionalne i Lokalne, 2(44), 92-117. Pozyskano z http://www.studreg.uw.edu.pl/pdf/2011_2_tomaszewski_zaleski.pdf. 
Ustawa z dnia 12 maja 2000 roku o zasadach wspierania rozwoju regionalnego. Dz.U. $2000 \mathrm{Nr}$ 48, poz. 550.

Ustawa z dnia 20 kwietnia 2004 roku o Narodowym Planie Rozwoju. Dz.U. 2004 Nr 116, poz. 1206.

Ustawa z dnia 12 grudnia 2006 roku o zasadach prowadzenia polityki rozwoju. Dz.U. 2006 Nr 227, poz. 1658 .

Ustawa z dnia 8 listopada 2008 roku o zmianie niektórych ustaw w związku z wdrażaniem funduszy strukturalnych i Funduszu Spójności. Dz.U. 2008 Nr 216, poz. 1370.

Barbara Rubacha, mgr, Uniwersytet Marii Curie-Skłodowskiej w Lublinie, Wydział Nauk o Ziemi i Gospodarki Przestrzennej. Absolwentka kierunku Turystyka i rekreacja na Uniwersytecie Marii Curie-Skłodowskiej w Lublinie, doktorantka na Wydziale Nauk o Ziemi i Gospodarki Przestrzennej. Zainteresowania naukowe autorki koncentrują się na problemach związanych z gospodarką przestrzenną oraz rozwojem regionalnym i lokalnym, w szczególności w aspekcie efektywności strategii rozwoju, przygotowania i realizacji projektów inwestycyjnych, zwłaszcza współfinansowanych z funduszy strukturalnych UE.

Barbara Rubacha, MA, Maria Curie-Skłodowska University (UMCS) in Lublin, Faculty of Earth Sciences and Land Management. Ph.D. student in the Faculty of Earth Sciences and Land Management. The scientific interests focus on the problems of spatial management, regional and local development, especially on the efficiency of local development strategy, preparation and realization of the investment projects, particularly of the projects co-financed by the structural funds UE.

\section{Adres/address:}

Uniwersytet Marii Curie-Skłodowskiej

Wydział Nauk o Ziemi

al. Kraśnicka 2 cd, 20-718 Lublin, Polska

e-mail: barbara_rubacha@wp.pl 